\title{
"Today at Playcentre, we ....": What values underpin narrative assessment in Playcentre?
}

\author{
Sue Stover ${ }^{\mathrm{a}}$ and Lia de Vocht $^{\mathrm{b}}$ \\ ${ }^{a}$ Auckland University of Technology \\ ${ }^{b}$ University of Canterbury
}

Narrative assessments are widely used in Aotearoa New Zealand's early childhood services, especially in the form of 'Learning Stories'. This sociocultural approach to assessment foregrounds the importance of identifying what is valued learning within a particular context. What does this look like within the context of the parent co-operative Playcentre? A small-scale qualitative study brought together focus groups of Playcentre parents to share what Learning Stories are being written, to explore their experiences in writing and using Learning Stories, and to consider what underlying values shape narrative assessment in Playcentres. A major finding is that adult learning and relationship building are key aspects of Learning Stories in Playcentres. The authors argue that because of the positioning of parents as both learners and Kaiako in Playcentre, assessment in Playcentre is fundamentally different to that in teacher-led services.

Keywords: Early childhood education - New Zealand, Playcentre, Professionalisation of early childhood education, Learning stories, Parent education, Parent-led early childhood education

Teachers working in licensed early childhood services in Aotearoa are expected to assess children's learning through formal documented assessment (Ministry of Education, 2017; Teaching Council of New Zealand/Matatū Aotearoa, 2019). What happens when those teachers are also the parents of the young children being assessed? And further, what happens when the parents are themselves learners within the broader field of early childhood education? This is the situation that occurs in Playcentres around Aotearoa New Zealand. A parent co-operative early childhood service, Playcentre draws together parents to be the teachers, the administrators and even the teacher educators of other parents (for information about Playcentre parent education and minimum requirements for supervision, see Playcentre Aotearoa, 2019). Experts, no doubt, on their own children and with likely expertise in other valuable areas, these parents arrive and begin participating as Playcentres' educators effectively as amateurs in the increasingly professionalised world of early childhood education (ECE) (Stover, 2016). Especially in their first months and years at Playcentre, parents are learners about assessment and what children's learning looks like; they are learners about Te Whāriki; and they are learners about what compliance requires of them collectively. Thus, in Playcentre the assessors are themselves learners. As parents they have a fundamentally different relationship with their children, than do early childhood teachers 
assessing other people's young children. We argue that as a result, assessment in Playcentre has significantly different purposes and processes to what occurs normally in a teacher-led early childhood service.

This paper reports on a small-scale qualitative research project which focuses on how parents engage as assessors of young children in Playcentre. A key finding is that in Playcentre, the experience of 'narrative assessment' (usually 'Learning Stories') occurs in the context of relationships with other parents. In contrast to teacher-led services, where teachers may seek 'parent voice' as part of the assessment (Hunt, 2016; Ministry of Education, 2004/2007/2009), in Playcentre, Learning Stories are the voices of parents.

The original data gathering of this paper was undertaken in 2016, before three important recent shifts: (1) the revision of Te Whāriki (Ministry of Education, 2017); (2) the creation of one national Playcentre entity and closure of the regional associations (New Zealand Playcentre Federation, 2019); and (3) the creation of one NZQA national Playcentre qualification in 2018. In addition, a new strategic plan for the childhood sector has been released (Ministry of Education, 2019). It indicates plans for addressing issues relevant to Playcentres, especially its chronic underfunding (Bailey \& Tamati-Aubrey, 2018).

While we acknowledge that these major changes will have had some impact on how narrative assessments will be understood, especially in terms of Playcentre education, we argue that our study remains relevant because the basic dynamics of a Playcentre continue. More specifically, that from their early days in Playcentre and as part of their responsibility as members of a Playcentre, parents are drawn into narrative assessment of children - their own and other people's children. This responsibility usually comes before there is full understanding of assessment practices. The value placed on parents as essential participants in their children's assessment, and the affordances required because those parents are learning while they are assessing, position Playcentre's approach to assessment as fundamentally different to what occurs in teacher-led early childhood services.

\section{Assessment understood in the context of marginalisation of parent-led EC services}

While diversity of provision of early childhood services is a sign of a healthy marketplace where parents have choices, policy choices at the national level have since 2002, largely privileged teacher-led services (Manning, 2018). In 2002 a highly applauded 10-year strategic plan for the ECE sector set out a course for wider participation by children, with increasing levels of qualifications for teachers and greater co-operation amongst agencies (Ministry of Education, 2002). A small but significant change in policy led to a distinction between teacherled and parent-led Early Childhood (EC) services. In the following years, incentives targeting the teacher-led services have worked to the disadvantage of parent-led services (Manning, 2018, 2019). For example, the launch in 2007 of a '20 hours free ECE' per week programme for children aged 3-5 years old eroded sessional provision (which was often limited to 15 hours per week). The effect has been that long day ECE has become affordable for many families.

The increase in mothers of young children entering the paid workforce has led to a high demand for childcare services. Profit making opportunities have meant a rapid growth in corporate provision of early childhood education with an emphasis on long-day services (Wells, 2016). As a result, many early childhood services that are community run - i.e., not 
for profit - and especially sessional (part day) services have been squeezed in a competitive marketplace (Mitchell, 2017).

While there has been a significant growth in the last 16 years in the early childhood sector, there has been a gradual, but significant decline in enrolments in parent-led services. As of 2018, there were 421 active Playcentres across the country (Education Counts, 2019). In 2000, there were 517 (Ministry of Education, 2017a). This provides the backdrop in which Playcentres currently operate and suggests that in the context of recent policy development, the parent-led services are thus becoming something of an historic anomaly. Both Playcentre and Te Kohanga Reo - two parent-led services endemic to Aotearoa New Zealand - have been profoundly influential on the foundations of the early childhood sector and its curriculum, Te Whāriki (May, 2009). However, their reliance on parents as volunteers has run counter to policy foregrounding parental participation in the national workforce (see for example, Early Childhood Education Taskforce, 2011), thus leaving the early childhood sector to be strongly influenced by the twin policy drivers of expanding the labour market, especially drawing in working mothers, and the market-driven model of provision (Mitchell, 2017; Stuart, 2018).

\section{Assessment linked to observations}

At the heart of Learning Stories lies the ability to closely observe the child, who they are, what is unique about them, what they are interested in. While historically Playcentre parents were not assessing children's learning, learning to observe children has been basic to the task and role of being a Playcentre parent for generations (Stover, 2011). Running records were required as part of Playcentre training and were usually analysed in terms of Piagetianinspired stages of development and of play (see, for example, Grey, 1974; Penrose, 1998). This style of observation and analysis reflected the accepted developmental approach of the time and Playcentre's origins as a site of parent education. The purpose of the observation was for the adult (usually the parent) to understand the child. Children's expression of self would become evident through informed observation and the desired outcome would be the parent/adult interacting more thoughtfully with the child (Stover, 2016). As an early Playcentre textbook says, "Observation changes our relationships" (Grey, 1958, p. 20).

In 1998 there was a major shift for Playcentres in two inter-related ways. One was the requirement to assess young children (Ministry of Education, 1998). This was new to the entire EC sector. While Playcentres had undertaken observations of children for decades previously, these observations were not a requirement - they were not linked to compliance or linked to licensing or government funding. Further, they were not described as 'assessing children'. Calling an observation 'an assessment' is a shift in discourse and re-enforced the move to educationalise the diverse sector (Stover, 2011). The second shift was the arrival of Learning Stories which were developed by Margaret Carr as a sociocultural assessment system that aligned with New Zealand's early childhood curriculum, Te Whāriki, which had been gazetted two years earlier (Carr, 1998; Ministry of Education, 1996).

In addition to the above shift, a major change occurred in how the assessor (the observing 'adult' in Playcentre) was positioned. The existing wisdom was that the observer attempted to strip away personal perspective in order to accurately see what was happening, and to describe what was happening in a way that anyone seeing the same event would be able to say, 'That is what happened. I saw it too'. However, Learning Stories positioned the 
assessor as part of the assessment documentation, thus instead of trying for objectivity, those writing Learning Stories are seen as writing from their own perspective of events. This is a movement away from 'objectivity' and towards 'subjectivity, away from the intentional 'detachment'. Relationships are at the core. According to the authors of Kei tua o pae, "Effective assessment practices reflect reciprocal and responsive relationships with people, places, and things" (Ministry of Education, 2004, p. 31). Within close personal relationships, learning occurs through intersubjectivity - experiences of joint attention when mental and emotional practices are applied together (Smith, 2013). Pleasure, respect and even affection can be part of a Learning Story. This emphasis on relationships and on the sociocultural context of learning is broadly supported by theorists like Urie Bronfenner and Lev Vygotsky (Smith, 2013). Although the emphasis is new, this prioritising of relationships has guided Playcentres for generations before Learning Stories were introduced.

By 2001, significant efforts in Playcentre were underway to introduce and normalise assessment using Learning Stories. In a Ministry of Education-funded professional development resource for Playcentres, Learning Stories are described as documenting "a package of decisions" and actions that a child makes (Stover, 2001, p. 190). However, there is no discussion of the 117 learning outcomes identified within Te Whāriki (Ministry of Education, 1996), nor advice about how these could be met. In contrast, there is empowering advice from Margaret Carr, who encouraged Playcentres - if they chose to use Learning Stories - to spend "quite a lot of time" brainstorming what they are looking for - what learning is valued - and building up shared language (Stover, 2001, p. 191).

The Playcentre Journal was also used to encourage members into new ways of working and thinking in terms of assessing children. A document analysis of 17 years of Playcentre Journals shows how Learning Stories were promoted by those in leadership roles within Playcentre. There is affirmation that parents can indeed assess young children, and there is also affirmation that the changes required can happen without undermining Playcentre philosophy and principles. This was evident in the earliest Playcentre Journal article in which a member of the Playcentre Federation's Education Committee lauded the compatibility of the (then) new curriculum Te Whāriki with Playcentre philosophy: "The things we have held dear - the value of play, families and communities being involved, a fully child-centred environment, integrated learning - were all incorporated in Te Whāriki's values-based, openended curriculum style" (Kitchen, 2001, p. 24). She highlighted Learning Stories' many advantages, including that new parents could write them. And compliance got a brief look in: she pointed out that using Learning Stories would be a way that could show that Playcentres were "using" Te Whāriki (p. 25).

A year later, another member of the Playcentre Education team told Journal readers that Learning Stories built on their familiarity with storytelling and Playcentre's traditions of intentional observations, reinforcing the value of documenting how children learn, rather than what children learn. In other words, the focus was to be on children's learning dispositions. Local contexts would decide what learning was valued and therefore what would be encouraged in local contexts (Reid, 2002).

Alongside this article is an account from Renwick Playcentre, which had introduced 'profiles' - effectively scrapbooks - initially "as a place to put our documentation, photos and children's artwork" which were made available to children and families to read and to contribute to. An outcome noted was that the profile books appeared to have helped enhance a sense of belonging, "by parents, as well as children" (Naus, 2002, p. 22). It also indicates 
that 'portfolios' were becoming more than the optional responsibility of individual parents collecting documentation about their own children.

Across the next decade, the articles on assessment tend to be reports on 'new' ways of seeing and documenting children's learning. Amongst the first of the Ministry of Education's 'Centres of Innovation', Wilton Playcentre researchers explored schemas (see for example, Cubey, 2007). In Canterbury, the Ministry of Education Teaching and Learning Research Initiative funded a study into young children's 'working theories'. This research produced a collection of case studies in which Playcentre parents had the opportunity to consider how to enable children's ideas to be more thoughtfully brought into visibility and documented through story telling (Davis \& Peters, 2010; Davis, Peters, \& Duff, 2010).

In 2012, Jill Farr revisited two Waikato area Playcentres that she had previously worked with as part a large professional development contract on sociocultural assessment using the Ministry of Education's resource Kei tua o te pae (Ministry of Education, 2004/2007/2009). Farr found that support for parents was the key to a Playcentre's capacity to sustainably assess young children using Learning Stories. That support included involving new parents in the process of building capacity in writing narratives, as well as ensuring ongoing access to, and engagement with children's portfolios (Farr, 2012).

These initiatives indicate that there are philosophical and practical aspects of Playcentre which are compatible with socioculturally framed narrative assessment. However, as one commentator has indicated, the Playcentre Journal tends to provide the good news stories (Manning, 2018). No wide-scale research is evident, nor articles or reflections on lived experiences that reflect systemic challenges of implementing Learning Story-based assessment in Playcentres.

However, looking more generally at the early childhood sector (including Playcentres), the Education Review Office (ERO, 2007, 2015) has repeatedly raised concerns about the quality of assessment practices. These may be explained, at least in part, by a recent survey of the EC sector, including Playcentres, which indicated that EC teachers' working conditions limit the time available for quality assessment (Cameron, McLachlan, \& Rawlins, 2016). The findings include the perception amongst early childhood teachers that writing up assessments is a compliance task - a key aspect of what is needed to satisfy ERO reviewers.

\section{Ethics and methodology}

This research grew out of personal and professional interests of the authors. Both have had long involvement in Playcentre, initially as Playcentre members attending sessions with their own children and then through extended involvement in Playcentre education and publications (see for example, de Vocht-van Alphen, 2006; Stover, 1998, 2001, 2011, 2016).

As part of an ongoing conversation, the question arose about how Learning Stories were understood and enacted within Playcentres. While we knew that Learning Stories had become normalised in Playcentre, and that there had been some intensive professional development and research with specific Playcentres, we also knew that there was no academic research into how Playcentre parents understood and enacted Learning Stories.

Following ethics approval from the University of Canterbury, Auckland University of Technology plus the New Zealand Playcentre Federation, the research was introduced to Playcentre members through the two associations and the invitation was made for centres to participate in two 'forums'. All those that accepted the invitation were accepted into the 
study. The forums followed an agreed semi-structured format which enabled discussion and debate. The forums were audio recorded and transcribed.

Of the seven Playcentres that opted to participate in the study, a diversity of Playcentres was quickly evident: different supervision models, large and small Playcentres, urban and rural. However, no attempt was made to connect research findings with specific Playcentres; the research thus focuses on Playcentres rather than any particular type of Playcentre. There were multiple forms of permission giving required and obtained: for the adults to agree to participate; for the centres to agree to the adults participating; for adults and children to agree to the Learning Stories; and portfolios to be included in discussion and used in the research project. Sue Stover led the two forums with the Playcentres in the North Island association; Lia de Vocht led the two forums with the Playcentres in the South Island association. Although we did not seek out experienced Playcentre members, all the research participants were either studying towards, or had completed Playcentre Course 3. At the time this was the minimum qualification for supervising a Playcentre session (Playcentre Aotearoa, 2018).

The focus of the first forums was on processes: what Learning Story templates are available and used, what normally happens in centres, how parents are introduced to writing Learning Stories, and how Learning Stories influence planning. The second forum focused on portfolios and considered more of the detail of the Learning Stories - what was documented, how learning was analysed, how they were presented, and what difference they made for children's learning.

In total, the focus groups considered over 50 Learning Stories. These Learning Stories were brought to the focus groups, and participants were encouraged to discuss their significance. These Learning Stories were gifted to the researchers as part of the project. The authors were thus working with data that included transcripts of four focus groups, plus about 50 Learning Stories.

(For a fuller account of the study, see de Vocht \& Stover, 2019; Stover \& de Vocht, 2017)

\section{Findings}

In analysing the transcripts of our focus groups, we recognised two broad areas reflecting underlying values. The first area is within the Learning Stories themselves. We argue that underlying values are evident in:

- the diversity of ways in which the Learning Stories were written

- what the Learning Stories focus on;

- who they were written for;

- how learning was recognised;

- how the Learning Story was used; and

- what, if any, analysis was written down as part of the documentation.

Underlying values also became evident when we considered:

- who was encouraged (and how were they encouraged) to produce a Learning Story;

- what (if any) feedback was given on what is written as a Learning Story;

- how writing and engaging with Learning Stories reflected and affected the culture of a Playcentre. 
Working through the Learning Stories that were provided by the participating Playcentres, we identified the following areas of valued learning:

(1) Authenticity. Children's individuality and personality are evident. The child is recognisable. Their mana is upheld. For example, "Your family of elephants came to Playcentre again today and you wanted to give them a bath..."

(2) Documenting children's interests. In some cases, this was a discovery for the Learning Story author but in many cases it was reinforcing the value of a child's interest. In some Learning Stories, this included hypothesising ('What do you think will happen? Why?') and sometimes making evident subject areas such as science. For example, "The last place we stopped was under a group of deciduous trees where we learnt that these are trees that lose their leaves in autumn and grow new ones in spring."

(3) Making connections. Often these were connections between the child and the Playcentre community as well as local neighbourhood. But connections were also made to the child's home and especially home culture, to distant family members, and to past experiences. For example: "John - you told us about a friend who had a cicada wing. It was nice that you shared your world outside of Playcentre with us."

(4) Affirming experiences at Playcentre. This was especially common for children who are relatively new at Playcentre. For example: "Thomas, your communication is amazing. You knew what equipment you wanted and where you wanted to put it."

(5) Naming and affirming capabilities and emotional states. For example, "What a considerate boy you are. I loved that you noticed how Mia was feeling and said "Sorry".

(6) Identifying learning dispositions and working theories. For example: "I then asked everyone what colour they would think would come next. Daniella said the green one. I asked why, she said because it was the smallest one."

(7) Using te reo, as well as using whakatauki and identifying aspects of tikanga: "For example: "Owen - you made the most of the lovely weather on Ramere and went o whakahaere waho. I loved how you paused for a moment as the warm wind blew the leaves around you. A real taste of ngahuru."

(8) Recognising aspects of Te Whāriki: For example: In response to a young toddler's tapping and sucking on rakau as part of tititoria, a centre co-ordinator identified 'Communication Goal 4 - 'Children discover different ways to be creative and expressive' pointing out how the child was learning to keep a beat and growing in familiarity with the Playcentre's repertoire of songs and chants.

(9) Identifying planning directions for adults: For example: "...further work on the relationship skills as he's newly on his own as Claire has just started school at the beginning of the term..."

\section{What underlying values are evident in how adults engage with Learning Stories?}

Within this study, a major underlying value was the importance that parents should be empowered by the process of engaging with Learning Stories. In the context of parents stepping into new roles and responsibilities at Playcentre, writing a Learning Story had the potential to be "overwhelming." Examples given included situations in which there were Playcentre parents who: 
- were uncomfortable with professional responsibilities being laid on them and those who were "put off by the jargon" (e.g., of Te Whāriki);

- were self-conscious about their ability to write - especially those with a learning disability and those whose first language was not English.

In response to such challenges, those in the focus groups recognised the need to build trust and to introduce responsibilities in a way that enabled new parents to be empowered to find the best 'step on' experiences for themselves and their families. For some new Playcentre parents, the encouragement to 'Write anything!' was a helpful start to their journey with sociocultural assessment. According to one participant, a prompting invitation might be 'Write down what your child likes doing'. For others, a Learning Story template gave some beginning insights about how children's learning might be recognised.

These first steps open new insights, conversations, and hopefully a drive to learn more about children and how they learn and grow. As one participant said, Learning Stories are a tool to get parents to:

...reflect more and to put on more of a teacher's hat as it were, so we're not just sitting there ignoring what's going on, sitting there in our own world (laughter). It's that engagement with what's happening and ... by writing it down you're putting it in quite an adult format, but then it's the conversations that come with it and it's that kind of changing what goes in your mindset.

For others, a helpful tuakana-teina relationship can evolve through sitting and observing alongside a mentor-parent. This can enable the new parent to notice what their own child is doing whilst at play.

Several participants talked about the two-edged sword of using exemplars to illustrate a 'good' Learning Story to relatively new Playcentre members. On the one hand, an exemplar can clarify expectations and illustrate how learning can be recognised. On the other hand, an exemplar can be seen as too complicated, or it can set too high a standard. One participant, with decades of experience in Playcentres, talked about the importance of using multiple examples of Learning Stories, some very simple as well as some that showed more complexity, especially regarding analysis of the Learning Story.

What was important, she indicated, was to see Learning Stories as an adult learning process that focuses not on perfect Learning Stories, but the parents' sense of belonging. A 'simple Learning Story' often involves photographs of the child at play or the child with other people who may be important to the child. These reinforce valued relationships, even if there is no illustration of a child's learning per se. The acceptance and inclusion of simple Learning Stories in a child's portfolio will hopefully encourage a child to recognise themselves in Playcentre with Playcentre-friendly relationships, as well as encouraging a new parent to keep going - keep noticing - and at some point, perhaps through Playcentre education, more complexity will start to appear in the stories.

\section{Documenting a child's life in and out of Playcentre}

Working through the Learning Stories, we found that in some of these, learning was not necessarily identified or emphasised. Some of what was collected as 'Learning Stories' could more accurately be labelled as 'documentation about play and relationships'. For example, Some Learning Stories were written in storytelling form, such as: "Ahoy there, Captain Yasi! 
Today you set off on a hunt for 'golden treasure' on the island. With your band of merry pirates, you wave the flag and set sail across the sea..."

And some were written in rhyme: "SPLASH SUMMER DAY: Way hey we're having fun today / Having wet and splashy water play / Sliding down the slippery slide / All the water makes for a great ride / Time to go home, to say good bye / Mummies and Daddies will have lots of washing to dry!"

Several Learning Stories consisted of a child's storytelling, as recorded by an adult: "Once upon a time, there was a big bad wolf. And what did it eat? Fish. And the Big Bad Wolf said, 'Yucky fish' and it dived into the water. A shark came...."

The Learning Stories are often written conversationally - or as a 'letter' to the child. An example: "When we arrived at Playcentre today, you told me you were going to get some toys out". But there are Learning Stories that are written as a commentary about the child. An example: "She decided to run...".

Others are written from the child's perspective. An example: "Today my mummy and daddy got married, it was such a lot of fun and a special day for us all... I was making everyone smile and giggle at me."

Several participants with experiences of other early childhood services, expressed appreciation of the "authenticity" of the Playcentre assessments. Here are some of their comments:

- "I remember getting Learning Stories from my daughter from kindy and finding them really jargony and trying to read them to Lucy and she would just zone out and I'd be trying to explain what that meant to her going "This is weird". So I quite like at our centre our coordinator and I try to do that too and keep it quite chit-chatty. Every now and again you throw in something really jargony just to show you know what you're doing (laughter). But I do like that about Playcentres, the stories are really accessible to the children."

- 'The thing I like about Playcentre books is they're all unique to that child. So quite often the books that I see in the pre-schools are all just like repetitive, they all have the word 'perseverance'; they persevered with this and they persevered with that. Whereas at Playcentre you have a mix of people and when you pick up a child's book, it's very much a family book and so I like the fact that it may not be perfect. It might have spelling mistakes in it, it might be handwritten, it might have playdough stuck to the pages, but I like that because I think it's real. It shows the child that they are valued and they are important and they're not just one of a number of children that happened to jump off the cable drum that day, because they persevered (laughter)".

- "I find with, because my kids go to preschool too, that they will have a learning goal and all the Learning Stories will only pertain to that. I kind of feel like there might be pressure on Playcentre to go that way .... whereas the thing I love, that you can write a Learning Story about whatever you want and it doesn't have to be only to one goal. I feel like you miss out so much of everything else that's going on when you're only looking at their persevering or... you know what I mean? I guess you don't get the same sort of follow on all the time thing that you do in a preschool one, but you get it, it's just more sporadic in amongst the other cool stuff that's happening'.

\section{Planning?}

While the Learning Stories often had evidence of forward thinking (the 'What next? step was completed), the focus group discussions indicated that Playcentre planning was much more 
complex than following up on Learning Stories. In other words, 'What next?' may not prompt any documented follow through. However, as one participant mused, because so much of what happens during a Playcentre session is child-led, adult plans can be laid aside. She explained what often happens in a Playcentre: "Like today for instance, the child came with [a plan to feed] the birds and thankfully we had some bird feeding apparatus." She explained that learning happens through "full engagement" between the child and the learning environment and that the adults present are part of the learning environment.

Some Playcentres use their end-of-session evaluations to hear from parents who had worked on Learning Stories during sessions, generating planning directions for future sessions. However, planning in Playcentres is often nuanced, situational, and undocumented. Participants in one focus group agreed that in their experience, Learning Stories were about transforming the author of the Learning Story. The effect was to build a more complex understanding of the child, and this influences how the adult would interact with the child in the future.

\section{The challenges of building capacity for assessment amongst Playcentre parents}

Although there was discussion in the forums about what made a 'good' Learning Story (the inclusion of children's language was one such indicator), there was also a general discomfort about expressing any judgement about other parents' efforts at writing Learning Stories. Participants in one focus group recalled a parent resigning from Playcentre in part because of criticism about how she had written a Learning Story. A more inclusive culture at Playcentre is usually encouraged. As one participant said: "Anything that people want to write is okay. You're not going to bag someone's idea and tell them that they can't write a story."

However, keeping opinions to oneself can come at a cost: one participant reflected on how her Learning Story had been altered - and its meaning altered as well. The story was posted on Google docs and it was revised by another parent, so that 'spatial' learning became 'special' learning. The author of the Learning Story about 'spatial learning' did not feel she could raise this with the parents concerned, despite the change significantly distorting the learning described in the Learning Story.

Any intentional drive to improve a parent's capacity to write a Learning Story presents ethical dilemmas between a parent's need to have a sense of belonging and any intention to show professional looking presentation of children's learning.

For a Playcentre parent with dyslexia, writing (especially handwriting) a Learning Story can bring up strong feelings of disempowerment which is understandable given that Learning Stories are a form of public writing. Disclosure of a learning disability can be personally challenging and requires real courage. One focus group participant recalled receiving a Learning Story with "horrific" spelling and she had to decide whether to let her child see "that spelling." For another participant, the relationship with parents has to be foregrounded: a Learning Story is a gift and spelling mistakes are okay: "It's kind of like with accents and people pronouncing things incorrectly. Actually, in a multicultural society, you have to learn to try and understand different accents... (Similarly, different ways of spelling are okay). You have to accept that."

There is no minimum standard of English competency set for membership of Playcentre. For Playcentre parents who are fluent in a home language other than English, some of the focus group members emphasised that the Learning Story is primarily for the child/ren in the story. With this emphasis, encouraging parents to write a Learning Story in 'their mother tongue' has helped to bring into strong visibility the multicultural nature of 
some Playcentres. Although some 'mother tongue' Learning Stories include a brief statement in English, one Learning Story shared with a focus group was written by a Mandarin-speaking Playcentre parent. She wrote a group Learning Story entirely in Chinese - with a number of photos to illustrate which included non-Chinese speaking children - so the Learning Story was posted into the portfolios of children who could recognise themselves in photos but who had to look to the Chinese parent for explanation of the text. This is a powerful provocation and an affirmation of a family's 'funds of knowledge' (Gonzalez, Moll, \& Amanti, 2005). However, the detail of the 'assessment' is not necessarily evident to a person without the capacity to read Chinese. So what may have built a sense of belonging for the Learning Story author and the author's child, may leave other parents' children (and even ERO reviewers) aware of their own linguistic limitations.

Several focus group participants referred to an expectation by ERO reviewers that they should be able to see a child's progress between Learning Stories. One Playcentre began a new system of 'post-its' - going back through Learning Stories and adding short observations and comments to try to make visible how a child's learning was progressing over time.

Writing Learning Stories during a session was seen as illustrating the significance of documenting children's learning, but also role modelling handwriting. However, what often occurs on session is photographs (for example, on a Playcentre parent's phone), plus some "scrawling" intended - later - for a Learning Story. For some of those participating in our research, there was a significant backlog of stories to write up; an indication of the fact that Learning Stories have to line up amongst the priorities of busy parents, ironically made busier by Playcentre commitments.

\section{Discussion}

As earlier generations of New Zealand families have experienced, Playcentre provides space for $21^{\text {st }}$ century parents to learn about themselves, about how children learn, and about how communities learn and grow. Looking more specifically at the 17 years or so of Learning Stories in Playcentres, the intentional documenting and curating of children's learning continues to help build a sense of belonging for parents and children. This would also be the case in a well-run early childhood centre. However, a key characteristic of Learning Stories in Playcentre is the vital role of parents in assessing their own children - and this is generally not the case in the vast majority of early childhood centres (see, for example, Hunt, 2016). Because of the co-operative nature of Playcentres, and the ongoing involvement of new parents, there is a continual adult learning project imbedded in the writing of Learning Stories.

A Playcentre guide to assessment explains the 'why' of assessment in Playcentre:

...to create a community of learners, where adults and children learn together, to help children find their passion and to guide them, to help adults and children view children as competent learners, to grasp what children are striving to understand so we can help them make sense of their world, .... to make children's world wider, more complex, more compelling. (Canterbury Playcentre Association, 2010, p. 4)

All these are evident in the experiences of Playcentre parents in this research study.

When considered as an indicator of 'quality' in Playcentre, Learning Stories are seen as building relationships. But the quality of Learning Stories in Playcentre does not necessarily 
show a strong understanding of Te Whāriki, or of sociocultural theory (which is the underpinning theory of Te Whäriki).

The intriguing thing here is that Playcentre parents may not use, and may not recognise, sociocultural theories of learning, but Playcentres have for more than half a century shown the power of sociocultural learning. Playcentre's historic and current approach to learning is inherently grounded in the child's play within their sociocultural context: the presence of both the parent and the child at Playcentre brings home and centre much closer than is possible in any teacher-led early childhood service.

The sociocultural nature of the Playcentres themselves means that Playcentres tend to reflect the nature of their communities - which means that Playcentres, one by one, have to adapt as their communities' change. Where neighbourhoods have a transient population, parents will likely move through Playcentre quickly. Where there are economic pressures on a family, a Playcentre mother may return to the workforce, opt to leave or diminish involvement in Playcentre, and make use of the relatively inexpensive early childhood services now available for children aged 3 to 6 years old. In the resulting high turnover of families at a Playcentre, relationships suffer. Institutional knowledge is also lost. A Playcentre's collective ability to build capacity in writing Learning Stories and assessing children is likely to reflect closely how well parents are supported, how much training has been achieved, and how stable the centre families are.

This is not dissimilar to the situation in ECE services more generally; the national survey of ECE teachers about assessment practices by Cameron et al. (2016) indicated that teachers recognised that Learning Stories were often done quickly. Working conditions, especially multiple and conflicting requirements of them, led to insufficient time 'off the floor' to produce quality documentation of children's learning. This suggests that even when EC teachers are fully trained, they may have limited ability to produce quality assessment.

Much of what is learned in Playcentre is 'caught' rather than 'taught' and 'practical wisdom' builds up over years of active participation. However, Playcentre training plays a vital role in introducing concepts and developing pedagogical practices. This training has been through a revolutionary change even since 2016 when this research was conducted. Regional Playcentre education has been replaced by a national qualification which reflects the outcome of the New Zealand Qualifications Authority's recent review of pre-degree qualifications in Early Childhood. As a result, Playcentre training has been overhauled and the focus is quite strongly on building pedagogical knowledge amongst Playcentre parents - in other words, emphasising ECE sector knowledge. Learning stories are now introduced at the very start of Playcentre training (Playcentre Aotearoa, 2018).

Two particularly challenging aspects of assessment are (1) how does assessment relate to planning in ECE? and (2) how can assessment be used to verify children's progress towards learning outcomes? Again, as discussed by Cameron et al. (2016) and Cameron, McLachlan, Rawlins, \& McLaughlin (2018) and highlighted by ERO reports (Education Review Office, 2007, 2015), these are challenges for the early childhood sector.

A number of important themes are evident in this small piece of research. While there are major changes in how observation and assessing happens in Playcentres, there are also patterns that continue to reflect the challenges and discoveries of parents learning alongside their children. There are also indicators where the sociocultural nature of Playcentres emphasis on local provision, local curriculum, local people starting their journeys in early childhood education by arriving as parents in Playcentre - is likely to rest somewhat uncomfortably alongside the 2017 version of Te Whäriki which amplifies the idea that 'kaiako' 
(a broad term that includes educators who are not necessarily qualified as teachers) are to show a child's progress (see, for example, Ministry of Education, 2017b, pp. 22 \& 63), and to link to and plan for specific learning outcomes (Education Review Office, 2019).

Te Whäriki 1996 positioned assessment as a means to improve an EC programme, and cautioned that "the needs of children, not assessment procedures, should determine the curriculum" (Ministry of Education, 1996, p. 29). Arriving 21 years later and into a more highly qualified EC sector, Te Whäriki 2017 articulates a stronger emphasis on assessment that makes 'learning visible' (see for example, p. 63). Children are tracked in order to show progress (see for example, p. 65). Similarly, the Education Review Office's (2019) discussion document on quality indicators foregrounds intentional planning arising from assessment.

The connection between formal 'assessment' and 'formal' planning is made more complex in Playcentre because of how much scope children are given to determine what happens during a Playcentre session. It was difficult to pinpoint examples of situations where intentional planning by Playcentre parents was guided by Learning Stories.

As such, it may also be useful to think in terms of 'many planners', with documentation of what results, rather than placing great emphasis on formal planning: "Playcentre's relationship-based way of operating is full of assessment activities that involve many parents and impact directly on planning decisions for [and with] children" (Stover, 2001, p. 58).

\section{Conclusion}

According to leading international educational policy researcher Mathias Urban (2008), modern society is built on the basis of increasing divisions of labour and this has encouraged development of institutions to take significant responsibility for the upbringing of young children. Policies in early childhood education and care in many countries, as in New Zealand, are grounded in a discourse of professionalisation. Although parents are foregrounded in New Zealand's early childhood curriculum, parent-led early childhood services have a disruptive influence on this modernist drive towards specialisation (Manning, 2018).

Playcentre parents are both the consumers of, and providers of the service that Playcentre provides. To continue to operate as licensed early childhood education services, Playcentres have to walk a complex road with competing requirements:

- to listen to and enable participation by a diverse group of families with young children;

- to listen to the requirements of a centralised performance focused policy regime which, while promoting the importance of 'local curriculum' (see for example, Ministry of Education, 2017, p. 2), are part of a larger policy tidal wave which marginalises and underfunds parent-led services (Bailey \& Tamati-Aubrey, 2018; Manning, 2018).

This affects how assessment of children occurs in Playcentres. In a sector which values both the emergent and pre-intentional curriculum, and where 'ako' is foregrounded, inviting all involved to be seen as learners and as teachers, Playcentre can both be applauded and seen as problematic or non-compliant.

We argue that in Playcentre narrative assessment - predominantly Learning Stories is rich in its content and contributes substantially to Playcentre as a community of learners. However, in this research, we have identified two potentially problematic aspects of assessment in Playcentres: that of the expectation of intentional adult teaching and that 
adults will show a continuity of documentation of learning. Both require a skill base, and both have implications for the workload placed on kaiako.

This is not a unique problem within Playcentre. Cameron et al. (2016) have identified 'time' for assessment and planning as a complicating issue in ECE more generally. However, it is problematic to even attempt to consider 'what is an appropriate workload for Playcentre parents?' While there are some paid - usually part-time - employees in Playcentre, Playcentre members are generally parents who volunteer their time, juggling commitments to Playcentre with their other responsibilities and interests. There is not necessarily any way to demarcate 'time off the floor to do Learning Stories' as is expected for professional early childhood teachers.

To conclude, we argue that assessment in Playcentre is fundamentally different to what happens in other early childhood settings, particularly teacher-led services. To support this argument, we point to the significant role played by parents as assessors. In Playcentre, the emphasis on 'we' (the child/parent dyad) is fundamentally different to the 'we' (teacherchild dyad) that exists in professionally run early childhood services. We know that the Playcentre child's story is - to a large extent - the Playcentre parents' story. The collective assessment of the Playcentre child still has to consider the feelings, understandings, and insights of the parents. We also suggest additional research is needed to identify more about how children's learning is understood by Playcentre parents. We argue that this should not be determined by policy makers and external reviewers. Further, we can argue that the power of the home-centre link is fundamentally more influential in children's growth and learning than, say, professional intentions in planning and interventions on session within a teacherled service.

While Learning Stories are celebratedly 'subjective', they are still written in most early childhood settings by an outsider looking in on the child's reality, their family, and their thinking. While 'intersubjectivity' is understood to recognise the 'shared space' between two subjects (such as a teacher and child; or between a parent and child), the unconditional and lifelong intersubjective relationship between parent and child is manifestly different to the conditional relationship that occurs in teacher-led early childhood services. Parents are a part of the 'we' that shapes the child's most basic identity.

\section{References}

Bailey, S., \& Tamati-Aubrey, A. (2018). Messages to the Minister: "Please update funding models". Early Education, 62, 25.

Cameron, M., McLachlan, C., \& Rawlins, P. (2016). "Assessment in ECE is overwhelming at times": Uncovering the challenges of assessing four year old children's learning. Early Education, 60, 12-16.

Cameron, M., McLachlan, C., Rawlins, P., \& McLaughlin, T. (2018). Assessment of, as and for learning. Early Education, 64, 18-23.

Canterbury Playcentre Association. (2010). Playcentre pakiwaitara: Weaving our stories, learning together. Christchurch, New Zealand: Canterbury Playcentre Association. Retrieved from https://www.slideshare.net/DaleneMactier/assessment-planningand-evaluation-in-playcentre

Carr, M. (1998). Assessing children's learning in early childhood settings: A professional development programme for discussion and reflection. Wellington, New Zealand: New Zealand Council for Educational Research. 
Cubey, P. (2007). Schemas and learning stories: The two are compatible and complementary. Playcentre Journal, 128, 20-22.

Davis, K., \& Peters, M. (2010). From fact to fiction, from animal expert to story teller. Playcentre Journal, 138, 20-23.

Davis, K., Peters, S., \& Duff, A. (2010). Working theories in action. Playcentre Journal, 139, 20-23.

de Vocht-van Alphen, L. (2006). Pig-hunting boots: Exploring sociocultural thinking in a Playcentre context. Playcentre Journal, 125, 29-31.

de Vocht, L., \& Stover, S. (2019). Assessment: When parents are learners, too: Part II. Playcentre Journal, 160, 28-31.

Early Childhood Education Taskforce. (2011). Agenda for amazing children. Wellington New Zealand: Ministry of Education.

Education Counts. (2019). Overview of licensed ECE services in 2018. Wellington, New Zealand: Ministry of Education. Retrieved from: https://www.educationcounts.govt.nz/_data/ assets/pdf_file/0010/192943/ECE-Summary-page-2Services-in-2018.pdf

Education Review Office. (2007). The quality of assessment in early childhood education. Wellington, New Zealand: Author.

Education Review Office. (2015). Continuity of learning: Transitions from early childhood services to school. Wellington, New Zealand: Author.

Education Review Office. (2019). Indicators of quality for early childhood education: What matters most. Wellington: Author. Retrieved from https://www.ero.govt.nz/howero-reviews/ero-reviews-of-early-childhood-services-and-kohanga-reo/whatmatters-most-in-high-quality-early-childhood-education-draft-evaluationindicators/\#outcome-indicators

Farr, J. (2012). Playcentre parents 'noticing, recognising and responding' to their children's interests: How Playcentre parents have managed to change to sociocultural assessment and curriculum processes. Playcentre Journal, 145, 30-33.

Gonzalez, N., Moll, L. C., \& Amanti, C. (2005). Funds of knowledge: Theorizing practices in households, communities, and classrooms. Mahwah, NJ: Lawrence Erlbaum.

Grey, A. (1974). Learning through play. Auckland, New Zealand: New Zealand Playcentre Federation.

Hunt, L. (2016). Learning snapshots: Enriching assessment by investigating child and family perspectives about learning. Early Education, 60, 17-21.

Kitchen, S. (2001). Learning stories: A useful tool for Playcentres. Playcentre Journal 110: 2425.

Manning, S. (2018). Struggling to maintain diversity: The marginalisation of Playcentre in government early childhood education and care policy. New Zealand Annual Review of Education, 23, 96-110. https://doi.org/doi:10.26686/nzaroe.v23i0.5286

Manning, S. (2019). Beyond the teacher/parent separation: Questioning the $100 \%$ qualified teacher policy. Early Childhood Folio, 23(1), 28-32.

May, H. (2009). Politics in the playground: The world of early childhood in postwar New Zealand ( $2^{\text {nd }}$ ed.). Dunedin, New Zealand: Otago University Press.

Ministry of Education. (1996). Te Whāriki: He Whāriki matauranga o ngā mokopuna o Aotearoa: Early childhood curriculum. Wellington, New Zealand: Learning Media. 
Ministry of Education. (1998). Quality in action: Te mahi whai hua: Implementing the revised statement of desirable objectives and practices in New Zealand early childhood services. Wellington, New Zealand: Learning Media.

Ministry of Education. (2002). Pathways to the future: Nga huarahi arataki: A ten year strategic plan for early childhood education. Wellington, New Zealand: Learning Media.

Ministry of Education. (2004/2007/2009). Kei tua o te pae. Wellington, New Zealand: Author.

Ministry of Education. (2017a). He taonga te tamaiti/Every child a taonga: Strategic plan for early learning 2019-29. Wellington, New Zealand: Author. Retrieved from https://conversation.education.govt.nz/assets/ELSP/Early-Learning-Strategic-10Year-Plan.pdf

Ministry of Education. (2017b). Te Whāriki: He Whāriki matauranga o ngā mokopuna o Aotearoa: Early Childhood Curriculum ( $2^{\text {nd }}$ ed.). Wellington, New Zealand: Author. Ministry of Education. (2019). He taonga te tamaiti / Every child a taonga: Early learning action plan 2019-2029. Wellington, New Zealand: Author. Retrieved from https://conversation-space.s3-ap-southeast-2.amazonaws.com/SES_0342_ELS_ 10YP_Final+Report_Web.pdf

Mitchell, L. (2017). Discourses of economic investment and child vulnerability in early childhood education. Waikato Journal of Education, 22(1), 25-35.

Naus, C. (2002). Documenting children's learning: The Renwick experience. Playcentre Journal, 113, 22.

New Zealand Playcentre Federation. (2019). Press release: Playcentre Aotearoa is now a single charitable trust. Wellington, New Zealand: Author.

Penrose, P. (1998). Take another look/Tirohia anō: A guide to observing children. Auckland, New Zealand: Playcentre Publications.

Playcentre Aotearoa. (2018). Education Information. Retrieved from https://www.playcentre.org.nz/current-members/education-information/

Playcentre Aotearoa. (2019). What is Playcentre? Retrieved from https://www.playcentre.org.nz/future-members/what-is-playcentre/

Reid, R. (2002). Learning stories: Narrative observations and learning dispositions. Playcentre Journal, 113, 20-21.

Smith, A. B. (2013). Understanding children and childhood: A New Zealand perspective. Wellington, New Zealand: Bridget Williams Books.

Stover, S. (2001). Planning for playcentres: A hands-on resource. Auckland, New Zealand: Ministry of Education \& New Zealand Playcentre Federation.

Stover, S. (2011). Play's progress? Locating play in the educationalisation of early childhood in Aotearoa New Zealand. Auckland, New Zealand: Auckland University of Technology. Retrieved from http://aut.researchgateway.ac.nz/handle/10292/2864

Stover, S. (2016). The educationalising of early childhood in Aotearoa New Zealand: Tracking "free play" 1940s-2010. Paedagogica Historica, 52(5), 525-541.

Stover, S., \& de Vocht, L. (2017). Assessment in Playcentres: Where has it come from? What happens now? Playcentre Journal, 156, 20-23.

Stover, S., \& de Vocht, L. (2018). Assessment: When parents are learners, too. Playcentre Journal, 159, 25-28. 
Stuart, M. (2018). 'Social investment' as political economy of education: Recent changes in early childhood education in New Zealand. Global Studies of Childhood, 8(1), 75-90. https://doi.org/https://doi.org/10.1177/2043610618763177

Teaching Council of New Zealand \& Matatū Aotearoa. (2019). Our code, our standard. Retrieved from https://www.teachingcouncil.nz/content/our-code-our-standards

Urban, M. (2008). Dealing with uncertainty: Challenges and possibilities for the early childhood profession. European Early Childhood Education Research Journal, 16(2), 135-152.

Wells, C. (2016). In whose interests? Looking back - thinking forward. Early Education, 60, 31-34.

Having recently completed 16 years in early childhood teacher education at Auckland University of Technology, Dr. Sue Stover is working as a freelance writer, editor and educator. Her interest in E.C.E. began in the 1980s when she was attending Playcentre with her three sons. This interest continues and as a Playcentre grandmother, she is again back in the sandpit with young children as well as helping to run courses for Playcentre parents.

Email: sue@stoverwatts.co.nz

ORCID: http://orcid.org/0000-0001-6804-776X

Lia de Vocht (PhD), University of Canterbury. Lia de Vocht has been working in early childhood education for several decades. She became interested in early childhood education as a parent in Playcentre, and has been involved at local, regional and national levels of Playcentre. Having recently retired from her senior lecturer role at the University of Canterbury, she is currently involved there in an adjunct role. Her research interests include teacher-child dialogue, children's agency and pedagogical documentation in early childhood.

Email: lia.devocht@canterbury.ac.nz

ORCID: http://orcid.org/0000-0002-1235-4135 